\title{
Discursos, representações e práticas numa história institucional: o museu Julio de Castilhos nos anos 1960-1980.
}

Andréa Reis da Silveira*

\section{Resumo}

O presente artigo apresenta resultados parciais da pesquisa realizada a respeito do Museu Julio de Castilhos, instituição museológica centenária, localizada em Porto Alegre, Rio Grande do Sul, em determinado período. O artigo pretende demonstrar as influências sofridas nos discursos, nas representações e nas práticas dos cinco diretores que atuaram no Museu Julio de Castilhos de 1960 a 1980, denominada Ditadura Civil-Militar. O Museu Julio de Castilhos, por meio do patrimônio material incorporado e selecionado no período, pelo campo atuante, da instituição, como significativo das identidades brasileira e rio-grandense, constituiu e divulgou uma imaginação museal no Rio Grande do Sul. Os acervos, enquanto patrimônios incorporados corresponderam ao entendimento de um modelo restrito de museu, num discurso erudito e numa interpretação tradicional de patrimônio, centrada em razão do estado.

Palavras-chave: Museu. História institucional. Ditadura civil-militar. Representações. Discursos.

\section{Speeches, representations and practices in corporate history: the Museum of Julio Castilhos in the years 1960-1980}

This paper presents partial results of the survey about the Museum of Julio Castilhos centennial museum institution, located in Porto Alegre, Rio Grande do Sul, in a given period. The article intends to demonstrate the influences suffered the discourses, representations and practices of five directors who worked at the Museum of Julio Castilhos the 1960-1980 season, called Civil-Military Dictatorship. The Museum of Castilhos through the built heritage material and selected the period, the acting field, the institution as significant identities Brazilian and Rio Grande, and was released a fancy museum in Rio Grande do Sul The collections while Stockholder incorporated 
corresponded to the understanding of a restricted model of a museum, a scholarly discourse and a traditional interpretation of heritage, centered on the grounds of the state.

Keywords: Museum. Institutional history. Civil-military dictatorship. Representations. Speeches.

\section{Introdução}

Este texto pretende apresentar determinados resultados da pesquisa desenvolvida a respeito do Museu Julio de Castilhos (MJC). Foram analisados neste trabalho os discursos, as práticas e as representações produzidas pelo campo ${ }^{1}$ (BOURDIEU, 1996) circundante ao Museu Julio de Castilhos, no período de 1960 a 1980. Verificou-se que o patrimônio museológico salvaguardado e exposto naquela instituição, a partir da ótica dos diretores do museu, facilitou uma imaginação museal (CHAGAS, 2009) para os museus do Rio Grande do Sul.

A preocupação que aqueles sujeitos sociais tiveram em ordenar narrativas com objetos e ações da memória oficial do Estado do Rio Grande do Sul, transformou o Museu Julio de Castilhos em um agente cultural centrado em razão do Estado.

O Museu Julio de Castilhos, conforme a definição proposta em Santos pode ser entendido como um "museu de influência" (SANTOS, 2006, apud HUDSON, 1987, p. 61). No protótipo museológico desenvolvido pelo Museu Julio de Castilhos, inspiraram-se, para desenvolver seus projetos de constituição ${ }^{2}$, diversas outras instituições da capital e do interior do Rio Grande do Sul.

Considerando que o Museu Julio de Castilhos estabeleceu-se como a instituição museológica mais antiga do Estado do Rio Grande do Sul, criada em 1903, justificase a razão do estudo. No entanto, essa carga de importância não garantiu que o Museu Julio de Castilhos tenha sua trajetória minimamente explorada e analisada em suas diferentes potencialidades. 
Para desenvolver a pesquisa, uma revisão bibliográfica ${ }^{3}$ foi reunida a fim de oferecer subsídios ao trabalho. Especificamente sobre o tema, são principais referências: a dissertação de Nedel (1999), que examina a implantação de feições regionalistas na memória oficial proferida no MJC durante os anos 1950 e o trabalho de Peretti e Giovanaz (2003), abordando o Museu Julio de Castilhos como lócus de produção de história nacional e regional.

Há outros trabalhos de grande relevância que tangenciaram estudos sobre a instituição Museu Julio de Castilhos ${ }^{4}$. Contudo, nenhum deles acercou-se do período histórico de 1960 a 1980 (a produção acadêmica a respeito dos museus no período que propõe este estudo está, ainda, em construção) e da abordagem proposta.

Tornar o Museu Julio de Castilhos objeto dessa investigação é refletir a respeito das muitas modificações pelas quais passaram e passam os museus do século $X X$ e início do XXI. Nesse sentido, a investigação também contribui para pensar a história do patrimônio museológico no Rio Grande do Sul. No argumento que Dominique Poulot (2009) apresenta, "a história do patrimônio é amplamente a história da maneira como uma sociedade constrói seu patrimônio" (POULOT, 2009, p.12).

Para o desenvolvimento da pesquisa e a reunião de condições para análise, ancorei os estudos sobre o MJC em documentos permanentes e periódicos ${ }^{5}$ de circulação local do período. A documentação arquivística permanente da instituição exigiu constante observação, uma vez que a ausência de regramentos operacionais de gestão provocou descontinuidades e esvaziamentos nos subsídios sobre as operacionalidades funcionais, problematizando a história institucional do Museu. As descontinuidades de fluxo informacional sobre os procedimentos e a complexidade da trajetória histórica do Museu fragmentaram o diálogo, a interlocução de identificação e comunicação da instituição Museu Julio de Castilhos. Processos, metas, organogramas, diretrizes, atas, correspondências e relatórios, bem como toda a gama de documentação museal produzida e guardada, são fontes que garantem a exploração, o acesso e a realização de estudos e reflexões a respeito da ação dos sujeitos à frente das instituições museais. Esses documentos denotam, ainda, a importância dos percursos institucionais como entendimento do campo da museologia, que vem buscando, com avanços e recuos, cada vez mais, o ponto de 
partida para práticas interdisciplinares nos museus. Estes, por sua vez, buscam seu lugar no alargamento da experiência da contemporaneidade e, para tanto, é preciso pensar-se.

O desenvolvimento deste escrito será apresentado em duas seções subsequentes. Na primeira seção, "Que museu é esse? Abrindo a caixa-preta", formulo uma breve discussão acerca do objeto de estudo, o Museu Julio de Castilhos, compreendendo dados a respeito de sua criação, em 1903, até o ano de 1954, quando se verifica que ele passa por uma tensão conceitual e de feições. O ano de 1954 foi um marco divisório para o MJC, quando passou por transformações, voltando-se fundamentalmente às questões históricas. Na segunda seção, "Uma interpretação da história do Museu Julio de Castilhos nos anos 1960-1980", apresento a ideia de que neste período os diretores, por meio dos acervos incorporados e mostrados, conduziram a discursos e práticas em um museu de história, que visava fortalecer o vínculo identitário criado no Estado do Rio Grande do Sul. Isso fez com que a instituição Museu Julio de Castilhos fosse percebida a partir de uma imaginação museal (CHAGAS, 2009).

Os objetos incorporados ao Museu (expostos ou guardados no "depósito", como era denominada a reserva técnica na época), em sua relevância simbólica e repercussão subjetiva, indicaram a relação de pertencer e construir um discurso identitário. Conforme Gonçalves (2005), os objetos demarcam ou expressam posições e identidades, organizando ou constituindo o modo pelo qual os indivíduos e os grupos sociais experimentam suas identidades. Como patrimônios, os acervos museológicos do MJC afirmaram valores e certificaram "verdades".

Nas seções deste artigo, serão feitas articulações do processo da pesquisa, em que são revisados princípios teóricos que dizem respeito ao patrimônio, identidade, discursos e representações. Para tanto, desenvolvi o entrelaçamento destes conceitos com o contexto da época, 1960 a 1980, como influência concreta nas ações propostas e desenvolvidas pelos atores sociais. 


\section{Que museu é esse? Abrindo a "caixa-preta"}

Utilizar o termo "caixa-preta", próprio da linguagem da aviação, para abordar o caso do Museu Julio de Castilhos e sua travessia histórica e museológica não é mera eventualidade. A "caixa-preta" pode ser entendida como um aparelhamento que preserva as informações de bordo trocadas entre os pilotos e a torre de controle de voo, permitindo investigar e resgatar dados da comunicação da aeronave. Aplica-se a definição para o Museu Julio de Castilhos, considerando que a instituição tem seus padrões de referência e seus códigos fechados, inclusos, como a caixa-preta de um avião.

Criado pelo Decreto n. 589, de 30 de janeiro de 1903, com o nome de Museu do Estado, o Museu Júlio de Castilhos recebeu a missão de evidenciar o estado do Rio Grande do Sul como um estado moderno, progressista e economicamente viável ${ }^{6}$. Foi criado como um museu com coleções predominantemente de ciências naturais, aos moldes das primeiras instituições criadas no Brasil: o Museu Nacional, no Rio de Janeiro, o Museu Paraense Emílio Goeldi, o Museu Paulista e o Museu Paranaense.

O final do século $X I X$ e a primeira metade do século $X X$ trazem uma onda de criação de museus, tanto na Europa quanto no Brasil. Para Schwarcz (2005), o século XIX conhece o apogeu das instituições de trabalho científico ou ciências naturais, sendo frequente designar o período compreendido entre fins do século XIX e meados da década de 1920 como a "era dos museus".

No Brasil, as instituições museológicas nasceram conduzidas pela proposta de institucionalização das ciências, constituídas na prática intelectual por médicos, engenheiros e naturalistas. Tais museus eram caracterizados pelo enciclopedismo e pela interpretação evolucionista da sociedade, cujos critérios naturalistas eram utilizados para divulgação de teorias raciais. Os museus científicos perduraram prioritariamente até a década de 1920-1930, dividindo espaço temático com o nacionalismo, fomentando construções simbólicas da nação brasileira, por meio de acervos celebrativos.

Ainda nesse período, outras instituições criadas impulsionaram um panorama propício para o desencadeamento da composição dos diferentes tipos de patrimônio 
museológico no Brasil. Os museus da história oficial inauguraram a consagração museológica da "história pátria", centrados no encorajamento e legitimação da consciência e da memória nacional, do conhecimento de personagens e fatos do passado, cultuando tradições construídas e representações da nacionalidade, ao exemplo do Museu Histórico Nacional, criado por Gustavo Barroso em 1922, no Rio de Janeiro.

A direção do Museu Julio de Castilhos transitou entre esses dois paradigmas museológicos, durante os primeiros 50 anos da instituição. Teve tendência de especialização marcada pelos exemplares de botânica, zoologia, mineralogia, distintamente, com um pouco de história e etnologia.

Os museus, como são concebidos hoje, são efeitos da modernidade. Museus são "sujeitos históricos" e estão sujeitos à história. Trabalham sob o mesmo registro epistemológico do chamado "pensamento ocidental" e são, portanto, invenções de formas de pensar e de ver o mundo. Nota-se que, ao longo do tempo, a própria trajetória do processo de musealização atravessou dilatações e redefinições de conceitos, na mesma dinâmica das mudanças que a sociedade teve. $\mathrm{O}$ próprio vocabulário técnico da área transformou-se para dar conta de novas realidades e paradigmas.

Em 1907, a instituição recebeu a denominação de Museu Julio de Castilhos, uma homenagem ao político falecido Julio Prates de Castilhos ${ }^{7}$. A alteração da denominação em nada afetou a concepção e a análise da proposta museal.

No mesmo ano de 1907, o governo estadual do Rio Grande do Sul, encabeçado por Borges de Medeiros, designou a residência que abrigou a família Castilhos, na Rua Duque de Caxias, centro de Porto Alegre, para receber o Museu do Estado, como mostra a reprodução fotográfica 1 , adiante.

Ainda hoje, o Museu Julio de Castilhos ocupa as mesmas instalações, porém acrescidas com a aquisição, incorporação e reformulação de uma casa anexa, ocorridas em 1978. 
Referenciar o nome do político positivista Julio Prates de Castilhos e a edificação, que foi sua residência, como sede principal do Museu, mesmo que a instituição Museu Julio de Castilhos não viesse a dedicar-se à memória castilhista, remete à estratégia e à preocupação do poder dirigente local com as seleções e construções possíveis sobre o passado. A proposta de criação de um museu, para perpetuar o mito (que ainda se apresenta em nomes de praças, ruas e avenidas pelo Rio Grande do Sul e pelo Brasil afora), endossa as representações de tradições que deveriam penetrar na sociedade gaúcha e que levavam ao imaginário coletivo de um passado glorioso, inventado como história do Rio Grande do Sul.

Era interessante para o poder político local daquele tempo histórico e social que, a sociedade rio-grandense se identificasse com os valores articulados pelo grupo político dominante. Cultura (museu), patrimônio e identidade contribuem para a estabilidade, para a permanência e para a continuidade dos referenciais, estabelecendo pontes simbólicas entre o passado e o futuro.

O Museu Julio de Castilhos iniciou sua trajetória como parte de uma tática ideológica, de uma construção histórica geradora de uma identificação de reconhecimento da ordem preestabelecida. (FELIX, 1998, p.1942). 


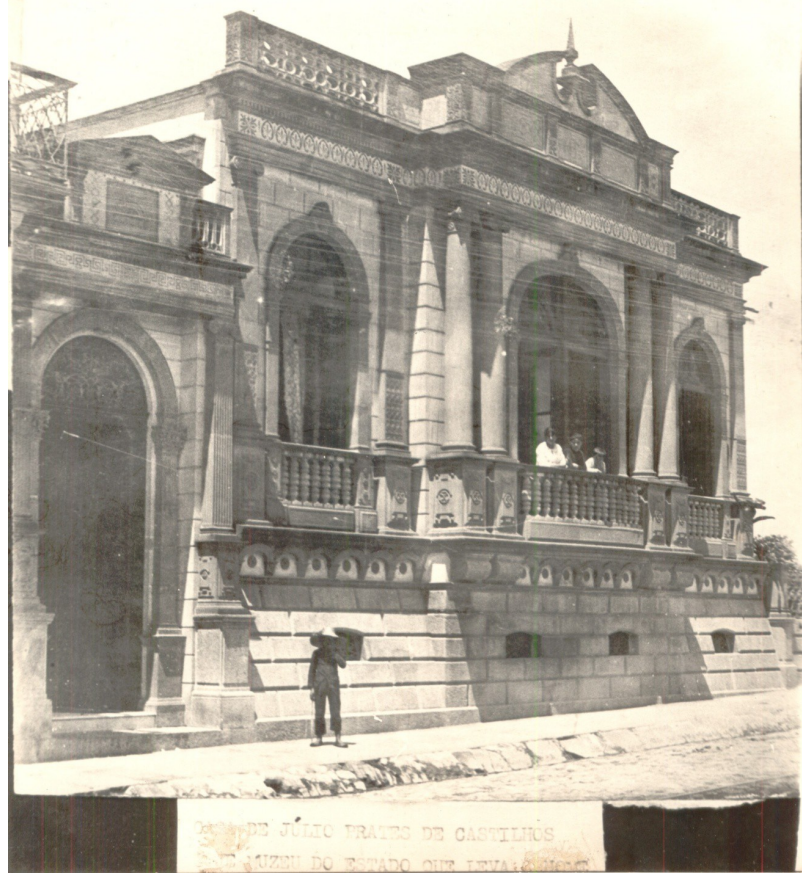

Figura 1 - Fachada da residência da família Castilhos e sede principal da instituição Museu Julio de Castilhos. Fotografia de Virgílio Callegari, 1901. Fonte: Acervo do Museu/coleção iconográfica $\mathrm{n}$. de registro 6967/134 ic.

Até meados de 1950, a instituição Museu Julio de Castilhos teve suas coleções repartidas em Ciências Naturais, Zoologia, Botânica, Mineralogia, Paleontologia, Geologia, seguidas em menor escala por objetos indígenas, artísticos e alguns objetos e documentos históricos. Um verdadeiro "bazar de maravilhas" (BITTENCOURT, 2000/2001, p.151).

O viés historiográfico do Museu Julio de Castilhos foi despertado em 1925, quando o Instituto Histórico e Geográfico do Rio Grande do Sul (IHGRGS) passou a coabitar a sede do museu. Era dele, em parceria com o museu que abrigou sua documentação, a tarefa de construir mitos fundadores regionais (e nacionais), sustentando a crença na evolução histórica, partindo das comunidades primitivas, indígenas e negros, até a chegada dos brancos europeus. Os textos e o repertório historiográfico produzido pelo IHGRGS muito influenciou o teor discursivo museológico dos diretores do Museu Julio de Castilhos no período de 1960 a $1971 .{ }^{8}$ Tanto o IHGRGS, quanto os museus perderam significativamente seu lugar 
privilegiado na produção da história para as universidades a contar dos anos de $1960^{9}$.

Mas a articulação do Museu com o passado, a história e a construção da identidade no Rio Grande do Sul, deu-se efetivamente a partir de 1954. Neste mesmo ano, foi criada pelo Governo do Estado do Rio Grande do Sul uma Divisão de Cultura dentro da Secretaria de Estado dos Negócios da Educação e Cultura. O MJC estava subordinado àquela Secretaria desde 1938, tendo sua reestruturação afetada. A Divisão de Cultura passou a centralizar as questões ligadas à cultura, no âmbito das instâncias institucionais, acarretando uma série de decretos que alteraram significativamente os rumos de atuação e representação do Museu Julio de Castilhos.

É pelo Decreto estadual n. 5.065, de 27 de julho de 1954, que o Museu Julio de Castilhos passou a conduzir, fundamentalmente, a história museológica do Estado. Ficou decidido que as coleções científicas, artísticas, bibliográficas e arquivísticas, adquiridas pelo Museu Julio de Castilhos enquanto espaço hegemônico da museologia no Rio Grande do Sul passaria a ser segmentada e delegada a outras instituições. Ao Museu ficava destinada a salvaguarda dos "objetos históricos". A condição de "museu de história" do Museu Julio de Castilhos, deu-se por uma relação particularizada ${ }^{10}$. A partir daquele momento, ele poderia vincular sua atuação museal exclusivamente à disciplina histórica.

As peças de Ciências Naturais e de Artes foram transferidas, em favor da criação de duas novas instituições. As coleções de borboletas, mineralogia, livros e as demais peças de Ciências Naturais do MJC propiciaram a idealização de um Museu de Ciências Naturais no Rio Grande do Sul (atual Fundação Zoobotânica). Pinturas e esculturas, peças relacionadas à arte, foram destinadas ao Museu de Artes do Rio Grande do Sul, em 1956. Esse processo da transferência das coleções foi lento. Iniciado em 1954, só foi concretizado em 1960, ainda com divergências nas interpretações de apropriação e salvaguarda de alguns acervos ${ }^{11}$, razão pela qual reconheço, nesta pesquisa, o período a partir de 1960, como o mergulho do Museu Julio de Castilhos no fato museal ${ }^{12}$ de modelagem histórica. 
Uma vez que o diretor do Museu durante o período de reformulação das coleções, Dante de Laytano, fazia parte de um seleto grupo de preservacionistas vinculados aos movimentos tradicionalistas ${ }^{13}$, cabe dizer que as conjecturas institucionais não dependem unicamente das ações políticas governamentais, mas também do entusiasmo de seus agentes na condução das políticas institucionais. $E$ isso é muito bem observado quando trabalhamos com a história do Museu Julio de Castilhos.

A separação das coleções e a mudança da missão ${ }^{14}$ do Museu Julio de Castilhos, com objetivo de assumir o papel de museu de história, são indícios de que os atores sociais contribuem, significativamente, para o desencadeamento dos discursos e das representações nos museus. No entanto, havia uma desorientação do campo museológico devido à falta de teorização formal e especialização museológica no período.

Quais objetos permaneceram no Museu Julio de Castilhos com o despejo das coleções de Ciências Naturais, Artes e de Documentos? Quais deles remetiam à tipologia histórica? Que conceitos de história e de museu foram articulados pelos diretores que assumiram a sua condução no período seguinte às definições do Decreto n.. 5.065? Nas áreas funcionais e técnicas, a mudança de rumo do Museu Julio de Castilhos trouxe alteração e ampliação no que se refere à dimensão estratégica, técnica e administrativa?

Ao longo de sua trajetória, o Museu Julio de Castilhos assumiu o papel de "guardião" de bens da cultura material ${ }^{15}$, considerando como patrimônios os diversos tipos de objetos representativos de uma parcela das tantas identidades sul-rio-grandenses. Ao darem entrada no museu, os objetos recebem valor de patrimônio, sendo ressignificados e mais ou menos explorados. Ou seja, cada conjuntura os revela para mais ou para menos, conforme seu tempo histórico social, com anacronismos, desarticulações, reconfigurações. O Museu vive amarrado à sua realidade, com fator de atualização ou desajuste.

As identidades são necessárias para operar no mundo, para situar em relação ao outro e organizar o sentido de quem somos. As representações significadas pelos agentes constroem os significados que foram associados ao Museu. Essas 
representações dizem como as coisas se tornam "verdadeiras" e são repetidas por meio do discurso. Pode-se observar isso no Museu Julio de Castilhos por meio da Sala Expositiva Gaúcha, em que um conjunto de objetos, vinculados à questão Farroupilha $^{16}$, denota a "preferência" rio-grandense em "pertencer" ao restante do Brasil. A Sala Gaúcha e seus objetos, que retratam o modo de vida rural no Rio Grande do Sul, leva a pensar nas estratégias de criação da identidade que podem manipular e, até, alterar a cultura. A identidade cultural é percebida como parte da identidade social, não vinculada apenas aos indivíduos, mas à definição social de um grupo que corresponde a sua identidade no conjunto social. Ao mesmo tempo em que inclui os membros do grupo que são idênticos sob certo ponto de vista, distingue os diferentes.

Nos anos de 1960 a 1980, ao atuar exclusivamente com a lógica histórica, o Museu e suas coleções nomearam, por meio de seus gestores, uma identidade cultural, "desenhando fronteiras internas e externas, principalmente na exclusão e marginalização". (HUYSSEN, 1994, p. 35).

O patrimônio instituído no Museu Julio de Castilhos é construção que se estabelece por um processo de atribuição de valores. Esses valores foram aferidos por um grupo, uma classe, que teve interesse em construir um discurso sobre a realidade que lhes interessava. O patrimônio depende de uma vontade política, sancionada pela opinião pública, para passar pelas diversas apropriações e construções identitárias.

Seus acervos, alguns inclusive transformados em patrimônio cultural da nação ${ }^{17}$, comportam intenções de interesses sociais determinados. Objetos de diferentes naturezas materiais e tipologias foram selecionados para a construção de uma identidade nacional e/ou regional, uma vez que o circuito expositivo apresentado pelo Museu Julio de Castilhos, desde os anos de 1960, é mediador de uma intenção, portanto uma narrativa não neutra. Tal análise pode ser vista com a observação da constituição classificatória das 29 coleções atuais do Museu Julio de Castilhos, Na tabela 1. 


\begin{tabular}{|c|c|c|}
\hline ACERVO & QUANTITATIVO & PERCENTUAL \\
\hline Iconografias & 2287 & $19,39 \%$ \\
\hline Etnologia & 2202 & $8,67 \%$ \\
\hline Numismática & 1437 & $12,19 \%$ \\
\hline Bibliografias & 204 & $10,21 \%$ \\
\hline Indumentária & 1140 & $9,67 \%$ \\
\hline Tesserologia & 974 & $8,26 \%$ \\
\hline Documentos & 667 & $5,66 \%$ \\
\hline Vários & 380 & $3,22 \%$ \\
\hline $\begin{array}{l}\text { Utensílios } \\
\text { diversos }\end{array}$ & 246 & $2,09 \%$ \\
\hline Medalhas & 205 & $1,74 \%$ \\
\hline Armas & 200 & $1,70 \%$ \\
\hline Regionalismo & 166 & $1,41 \%$ \\
\hline Condecorações & 132 & $1,12 \%$ \\
\hline Maquinaria & 74 & $0,63 \%$ \\
\hline $\begin{array}{c}\text { Objetos de uso } \\
\text { pessoal }\end{array}$ & 72 & $0,61 \%$ \\
\hline Arquitetura & 69 & $0,59 \%$ \\
\hline Bandeiras & 61 & $0,52 \%$ \\
\hline Mobiliário & 61 & $0,52 \%$ \\
\hline Artes náuticas & 38 & $0,32 \%$ \\
\hline Escravatura & 37 & $0,31 \%$ \\
\hline $\begin{array}{l}\text { Instrumentos de } \\
\text { trabalho }\end{array}$ & 33 & $0,28 \%$ \\
\hline Arreamento & 27 & $0,23 \%$ \\
\hline Missões & 25 & $0,21 \%$ \\
\hline $\begin{array}{c}\text { Objetos } \\
\text { decorativos }\end{array}$ & 22 & $0,19 \%$ \\
\hline Heráldica & 11 & $0,09 \%$ \\
\hline $\begin{array}{c}\text { Instrumentos } \\
\text { musicais }\end{array}$ & 07 & $0,06 \%$ \\
\hline Sigilografia & 06 & $0,05 \%$ \\
\hline Filatelia & 04 & $0,03 \%$ \\
\hline
\end{tabular}

Tabela 1 - Fonte: Sistema de documentação museológica digital do Museu Julio de Castilhos, Donatto 3.0. Consulta e acesso em 2010.

Percebe-se que os objetos, do modo como estão configurados no Museu Julio de Castilhos, passam por várias formas de interpretação de uso e função, demonstrando a historicidade daquele museu e a luta pelos significados atribuídos à 
instituição. Quanto à realidade, os referidos objetos estão dissociados da promoção e do desenvolvimento da conscientização histórica, em que não se constata a dimensão social, temporal e transformadora da sociedade, precisando de pesquisa cultural e educacional.

Pela análise desta tabela, verifica-se que as coleções mostram que a identidade riograndense assume lugar central no Museu. $O$ museu torna-se útil a um corpus específico de construções sociais arbitrárias, situadas como naturais e universais de representações excludentes.

No discurso construído através da incorporação daquele tipo de objeto, o visual prepondera. A seletividade dos bens demonstra uma simulação da sociedade, sustentando o que Nestor Canclini (1997) coloca sobre o que o patrimônio cultural expressa, ou seja, uma luta simbólica e material entre classes, etnias e grupos.

Em face disso, cabe ressaltar que artefatos de origem popular também são representativos da cultura e da identidade de um lugar, de um território, e também demandam reconhecimento dos museus; o que não é o caso no MJC. No Museu Julio de Castilhos dos anos de 1960 a 1980, os bens reunidos por seus diretores, como representativos da história do Estado ou da identidade da sociedade riograndense, não pertencem realmente a todos, ainda que o discurso e a narrativa concretizem a aparência de os estar representando. Como exemplo, temos a representação da cultura negra exclusivamente por objetos usados para castigar escravos. A construção da identidade se faz no interior de contextos sociais que determinam a posição dos agentes e orientam suas escolhas. A formação do Rio Grande do Sul pela presença negra (e indígena) é negada, com exceção do trabalho escravo, comparecendo de modo simbólico em eventos pontuais como carnaval e futebol.

A musealização daqueles objetos em exposições no MJC gerou significados de diferenças. Isso pode ser notado quando o projeto Trem da Cultura, tratado no próximo tópico deste artigo, passa a mostrar determinados acervos considerados superiores e que merecem ser observados por sua qualidade ilustrativa e documental. Descontextualizados, não problematizados na formação de sentidos, 
combinam referências de coerência imaginária; e servem a propósitos estéticos, cuja vitalidade de comunicação, linguagem e conhecimento histórico se perderam, quando expostos e ressignificados pelo Museu.

Identidade e memória são relações consagradas por diversos autores como Le Goff (2003), Pollak (1992), Hall (2011), Chartier (1990), entre outros que aprofundaram o assunto. A memória pode ser entendida como um estratagema ativo para a identidade individual e coletiva, também como um instrumento de poder. A identidade criada reflete o ideário de um grupo social, por meio do patrimônio. No caso do período em estudo, a coletividade vivia um momento de tensão e estranhamento, desejando fortalecimento de suas fronteiras, reconhecimento de seus modos de ver e perceber a realidade, através do autoritarismo. A cultura e o imaginário popular acerca do papel e do discurso de um museu de história ${ }^{18}$ foram manejados para fundamentar construções nacionalistas. Também uma parte do discurso de identidade do Museu Julio de Castilhos adquiriu feição regionalista. (NEDEL, 1999, p. 7). Julgamento e decisão entram no jogo da criteriosa esfera patrimonial da cultura e da política.

No período de 1960 a 1967, quando foi criada a "Sala Gaúcha", na qual eram dispostos exemplares de artefatos, que remetiam às lidas do homem do campo e da estância; objetos bélicos, de conflitos e lutas que reafirmavam o discurso da opção nacionalista do Rio Grande do Sul e; ainda, peças do universo masculino. Os artefatos bélicos, na sua maioria, remetem ao Episódio Farroupilha, conforme nos explica Pesavento: "[...] a Revolução Farroupilha, nos manuais oficiais de história nacional, foi o acontecimento pelo qual o Sul entra, definitivamente, na história do país e pelo qual é lembrado". (PESAVENTO, 2009, p. 251).

Os acervos da Sala Gaúcha do Museu Julio de Castilhos, trazidos de Centros de Tradições Gaúchas do interior do Rio Grande do Sul, são constituídos por objetos de compensação simbólica, mediadores de um estereótipo que endossa "um capital simbólico representado pelo culto às tradições gaúchas". (PESAVENTO, 1993, p. 393). Mais do que isso, incorporados como patrimônio museológico do Rio Grande do Sul, anunciam a permanência do cerco conservador cultural, político, ideológico e simbólico da época, refletido por meio das ações museais. Muitas das peças 
adquiridas ${ }^{19}$ como acervo do Museu Julio de Castilhos, no período de 1960 a 1980 , podem ser ainda entendidas como semióforos - "pontes entre o mundo visível e o invisível" -, suportes materiais de ideias que perderam seu valor de uso e foram valoradas e ressignificadas como preciosidades, servindo à exposição, ao olhar e à admiração (POMIAN, 1984, p. 53). Os semióforos do MJC, demonstrados no Quadro 2 , foram colecionados com o que há de tradicional, deixando de fora a diversidade de possibilidades identitárias formadoras do estado do Rio Grande do Sul e do Brasil. O semióforo tradicional garante a continuidade no tempo e a continuidade da cultura produzida pelo Museu. 


\begin{tabular}{|c|c|c|c|c|c|c|}
\hline Coleções & $\begin{array}{c}\text { Derly } \\
\text { Chaves } \\
(1960- \\
1967)\end{array}$ & $\begin{array}{c}\text { Rocha } \\
\text { Almeida } \\
(1967-1971)\end{array}$ & $\begin{array}{c}\text { Ivone } \\
\text { Martini* }^{*} \\
(1971- \\
1973)\end{array}$ & $\begin{array}{c}\text { Moacyr } \\
\text { Domingues } \\
(1973)\end{array}$ & $\begin{array}{c}\text { Joaquim } \\
\text { C. de } \\
\text { Moraes } \\
\text { (1974- } \\
\text { 1981) }\end{array}$ & $\begin{array}{c}\text { Total de } \\
\text { peças } \\
\text { por } \\
\text { Coleção }\end{array}$ \\
\hline Armaria & 12 & 1 & 2 & 2 & 24 & 200 \\
\hline Arquitetura & 8 & 2 & 0 & 0 & 10 & 69 \\
\hline Arreamento & 4 & 0 & 0 & 0 & 4 & 27 \\
\hline Arte náutica & 0 & 0 & 0 & 0 & 1 & 38 \\
\hline Bandeiras & 2 & 0 & 0 & 0 & 22 & 61 \\
\hline Bibliografia & 6 & 2 & 0 & 1 & 41 & 795 \\
\hline Condecorações & 12 & 0 & 0 & 0 & 77 & 132 \\
\hline Documentos & 34 & 13 & 1 & 3 & 117 & 666 \\
\hline Escravatura & 0 & 0 & 0 & 0 & 0 & 37 \\
\hline Etnologia & 4 & 0 & 0 & 0 & 74 & 2.202 \\
\hline Filatelia & 0 & 0 & 0 & 0 & 0 & 5 \\
\hline Heráldica & 3 & 0 & 0 & 0 & 0 & 11 \\
\hline Iconografia & 28 & 16 & 6 & 0 & 217 & 2.287 \\
\hline Indumentária & 81 & 43 & 1 & 21 & 151 & 1.140 \\
\hline $\begin{array}{l}\text { Instrumentos de } \\
\text { trabalho }\end{array}$ & 0 & 0 & 0 & 0 & 0 & 33 \\
\hline $\begin{array}{l}\text { Instrumentos } \\
\text { musicais }\end{array}$ & 0 & 0 & 0 & 0 & 2 & 7 \\
\hline Máquinas & 1 & 1 & 0 & 0 & 12 & 74 \\
\hline Medalhas & 9 & 0 & 0 & 1 & 48 & 205 \\
\hline Missões & 0 & 0 & 0 & 0 & 1 & 25 \\
\hline Mobiliário & 36 & 0 & 0 & 1 & 2 & 61 \\
\hline Numismática & 38 & 0 & 0 & 0 & 48 & 1.437 \\
\hline $\begin{array}{l}\text { Objetos de uso } \\
\text { pessoal }\end{array}$ & 10 & 7 & 0 & 0 & 11 & 72 \\
\hline $\begin{array}{l}\text { Objetos } \\
\text { decorativos }\end{array}$ & 0 & 0 & 0 & 0 & 2 & 22 \\
\hline Regionalismo & 70 & 0 & 0 & 0 & 58 & 166 \\
\hline Sigilografia & 0 & 0 & 0 & 0 & 1 & 6 \\
\hline Tesserologia & 28 & 0 & 0 & 0 & 40 & 974 \\
\hline $\begin{array}{l}\text { Utensílios } \\
\text { domésticos }\end{array}$ & 13 & 1 & 0 & 0 & 49 & 246 \\
\hline Vários & 50 & 22 & 1 & 2 & 84 & 380 \\
\hline Viaturas & 0 & 1 (lambreta') & 0 & 0 & 0 & 4 \\
\hline
\end{tabular}

Tabela 2 - Dados quantitativos relacionados à incorporação de acervos no Museu Julio de Castilhos durante o período de 1960 a 1980. A tabela leva em consideração somente os objetos que possuem registro com data de entrada (registros sem datação exata da entrada não foram considerados). Todos os dados presentes nesta tabela foram pesquisados através do Banco de Dados do Sistema Donatto 3.0, instrumento de documentação eletrônica do Museu Julio de Castilhos. Fonte: Arquivo permanente da instituição 
Nas escolhas e no ordenamento dos objetos realizados pelos diretores da instituição, para disponibilização ao público do Museu, estão presentes lembranças e esquecimentos. Enquanto expostas, as peças formalizam uma fala que permite entender a função simbólica e social da instituição. Um "museu-templo" (GONÇALVES, 1995) que não permite a compreensão do universo de possibilidades e de relações implícitas, do que seja a formação da sociedade rio-grandense, por diferentes tipos de pessoas que nem sempre estão contempladas nas coleções museais.

Nas incorporações das peças e na exposição delas para o público, o Museu sustenta a memória e a hegemonia de um grupo, do qual ficam excluídos os negros, as mulheres, os imigrantes, entre outros temas, atores e argumentos. Os artefatos representativos desses indivíduos, sujeitos históricos que não foram musealizados ${ }^{21}$ e, portanto, estão à margem da construção da história do Estado, oferecem possibilidade de reflexão sobre o modo como a história contada pelo Museu Julio de Castilhos articula as relações entre e com esses sujeitos. A recepção desses patrimônios pelos públicos e o momento da história em que aparecem, é configurada pela interpretação, pela identificação, pelo impacto, pela aceitação e pela duração.

Durante a gestão do general Antônio Rocha Almeida, diretor do Museu Julio de Castilhos, nos anos de 1967 a 1971, foram congregadas ao acervo algumas peças atribuídas como da participação feminina na sociedade rio-grandense. Não é interesse deste texto, discutir as representações de gênero no Museu Julio de Castilhos; no entanto, cabe citar roupas elegantes de festa, chapéus, joias, luvas, leques, objetos de lidas domésticas (culinária e costura), entre outras representações que pertenceram a Carlinda Borges de Medeiros e a Honorina Castilhos, esposas dos dois principais articulistas da política positivista riograndense da Primeira República. Os acervos sobre as mulheres nas coleções (iconografias, indumentárias, acessórios e de uso doméstico) do MJC conferiam um caráter natural ao papel da mulher, ao significado do que é ser mulher, salientando a desigualdade entre os papéis históricos dos homens e das mulheres. Para elas, e as roupas das esposas dos políticos Antônio Augusto Borges de Medeiros e Julio de Castilhos demonstram, a significação simbólica do papel feminino almejado estava 
no ideal da casa e da maternidade, limitada ao espaço privado residencial. Estereótipos de gênero dificultam as relações entre as pessoas, e o Museu Julio de Castilhos, particularmente neste sentido, reforçou essa maneira de interpretar o mundo.

As representações sociais institucionalizam-se por meio de palavras, sentimentos e condutas, simbolizando atos que parecem comuns, mas não são. É uma forma de conhecimento social, construída pela própria sociedade. O Museu Julio de Castilhos, representando a sociedade rio-grandense enquanto espaço de cultura, educação e história, conforme o discurso de missão institucional preconizado pelos diretores do período deste estudo reconheceu e reproduziu as representações e práticas, sem desmistificá-las, tornando-se um espaço unívoco e autoritário. Daí a sua importância enquanto espaço político que leva a repensar e articular a sociedade e repensar-se enquanto instituição socialmente ativa.

As representações moldam fortemente o social, incutindo imaginários de modelos e práticas de como a sociedade necessita agir. (FOUCAULT, 1970). A história representada no Museu Julio de Castilhos pode ser considerada um "teatro" da memória, alimentado, de forma consciente ou inconsciente, por seus diretores, assim investidos pelo Estado, com o objetivo de edificar interpretações de pertencimento, supressão, triagens e fixações. A instituição Museu Julio de Castilhos pautou sua representação da realidade e sua musealização em recortes históricos que encurtaram a vitalidade de comunicação, linguagem e conhecimento histórico potenciais de um típico museu de história. O reconhecimento coletivo do Museu tornou-o funcionalmente resistente aos cuidados e desafios da museologia social.

\section{Uma interpretação da história institucional do Museu Julio de Castilhos nos anos de 1960 a 1980}

A década de 1960 inicia, para o Museu Julio de Castilhos, sob a égide de um projeto. No decorrer dos procedimentos de análise sobre o período de 1960 a 1980, demarquei quatro etapas, momentos assimétricos de condução das relações funcionais, estruturais e das inclusões públicas do Museu. Esses quatro momentos foram enquadrados numa sequência lógica e linear, para serem vertidos em objeto de estudo do Museu Julio de Castilhos. O conjunto de informações das gestões que 
operaram a condução do Museu mostrou uma metodologia de trabalho, assim constituída: anos de 1960 a 1967 - Gestão Derly Chaves; 1967 a 1971 - Gestão Antônio Rocha Almeida; 1971 a 1973 - direções interinas; 1974 a 1980 - Gestão Joaquim Carlos de Moraes.

Como apreciação de cada gestão, criei uma tríade sintética, composta pela convergência do legado das administrações estudadas focadas na infraestrutura, nas relações institucionais e na administração das coleções. Também foram considerados dados biográficos dos diretores. A minibiografia dos diretores mostrouse interessante uma vez que as trajetórias individuais, desejos, origens e as complexas relações em que esses atores viveram, influenciaram seus modos de conduzir a instituição Museu Julio de Castilhos. Cada um dos agentes buscou reunir consigo acertos basilares. A posição de cada um deles, e a capacidade de concentração simbólica, econômica, cultural e política, determinava o que cada um podia fazer no Museu, sujeitos à regulação do estado.

Entre 1960 e 1967, na gestão de Derly de Azevedo Chaves, os dados da pesquisa remeteram ao entendimento de que a consolidação do desmembramento das coleções do Museu e sua distribuição a outras instituições, devido ao Decreto $\mathrm{n}$. 5.065, de 27 de julho de 1954, facultaram ao Museu Julio de Castilhos um teor discursivo pautado como museu de história.

O diretor Derly de Azevedo Chaves, pastor metodista, em seu discurso de posse, advertiu para a sua concepção de história e de museu: "[...] Povo sem história é povo sem vigor. O Museu Julio de Castilhos é a escola viva de nossas imperecíveis tradições e templo de cultura e civismo"22. Os documentos analisados, como o discurso de posse, correspondências expedidas e relatórios de gestão indicam influência positivista no pensamento e na realidade prática desse diretor. Ele, que foi ex-pastor metodista, vereador da Câmara Municipal de Porto Alegre e Deputado Estadual, compreendia que a "organização da sociedade se devia à questão legal e a utilidade das coisas servia ao aprimoramento"23.

Sua performance no Museu ressalta a possibilidade que os museus possuem de construir e manusear a realidade histórica. Isso fica claro ao verificar a articulação 
do discurso sobre o Museu, como "instituição moderna, dinâmica e didática". Essa acepção discursiva de polarização: novo (moderno) em oposição ao velho, e dinâmico em contraste ao contemplativo, era desenhada para demonstrar pontos fortes, símbolos da ideologia, da cultura, e tinha como intuito criar uma visão profissional de museu, contraposta ao amadorismo, garantindo autoridade e prestígio.

Interessa salientar que o quadro social e político, a conjuntura externa da instituição, a exemplo dos acontecimentos do movimento da Legalidade em 1961, o Golpe Militar de 31 de março de 1964 e o Ato Institucional de 1965, indiscutivelmente, abalaram a condução do Museu, quando verbas para obras de manutenção e modernização minguaram. Até as doações de acervo e a organização técnica fundamentalmente, seguiram os preceitos do diretor Derly Chaves. Cortes de verbas atacam prioritariamente o setor cultural e, especificamente, o Museu; o qual solicitava aportes aos órgãos governamentais, mas nem sempre era atendido em suas demandas.

A fragilidade do MJC teve repercussões que levaram a ameaças de prejuízo das "relíquias do Museu". Parte da imprensa, os periódicos: Correio da Manhã (25/7/1964), Diário de Notícias (17/12/1967) e um artigo de Abdias Silva (Folha da Tarde, 1967) reclamavam das más condições do prédio que implicavam a deterioração do acervo. É o caso especialmente das 622 armas que compunham as Coleções General Osório, doadas em 1956, por Mário Martinez, alijadas do Museu. As peças adquiridas eram prioritariamente advindas das doações de particulares. Os mecanismos de aquisição e conservação envolvem associações e representações de um grupo que molda, culturalmente, ações e contextos, pela ideia da perda. $\mathrm{O}$ distanciamento dos objetos no tempo e no espaço provoca o desejo de autenticidade e de permanência.

Esse sistema de doações (e o discurso da perda) formava uma rede de relações interpessoais, que dava um viés de cultura associada à erudição ao seu acervo museológico, numa dimensão separada da experiência cotidiana e das relações sociais. O Museu era visto a partir da representação da apropriação de objetos para 
contemplação, os quais legitimavam uma hierarquização social, pautada na valoração de tais vestígios.

Nesse período, os objetos, recebidos como acervos identitários e pela valoração de sua testemunhalidade dos eventos históricos, eram catalogados em fichas do Museu Histórico Nacional (Rio de Janeiro), tecnicamente adaptadas ${ }^{24}$.

Enquanto o Brasil e o Rio Grande do Sul faziam História com as passagens marcantes do período entre 1961 e 1967. Esses acontecimentos históricos não eram registrados pelo Museu e até os documentos administrativos desapareceram. Aparentemente, o Museu de História Julio de Castilhos passou incólume à História, mantendo sua narrativa conformadora. O fato de que esses eventos históricos, de significados políticos e culturais, passaram à margem do processo museológico, demonstra que significados e práticas foram negociados interna e externamente ao Museu Julio de Castilhos.

A estruturação criada por Derly Chaves dentro das salas expositivas ${ }^{25}$ demonstrou uma ordenação que seguia uma sequência cronológica de acordo com a historiografia oficial brasileira. Tais narrativas diminuíam a possibilidade da experiência, passando um conteúdo de mera assimilação e informação.

Entre 1967 e 1971, o diretor do Museu Julio de Castilhos foi Antônio Rocha Almeida, um general do Exército. O governo Costa e Silva (1967-1969) acabara de pôr em vigor a Constituição promulgada em 1967, imposição arbitrária que permitiu à Lei de Segurança Nacional submeter crimes políticos aos tribunais militares. A cada ano subsequente, o princípio da "segurança nacional" privava os cidadãos dos direitos da cidadania, por meio da censura prévia, do fim das eleições diretas, do bipartidarismo, do fechamento do Congresso Nacional e do Ato Institucional n. 5, por exemplo, (GASPARI, 2002). Mas não sem resistência. As medidas geravam uma sucessão de lutas e oposições contra a ditadura, refutadas pela repressão dos militares. Um militar com vínculos junto à intelectualidade institucionalizada firmava relações de aprovação com o discurso aceito e atinente ao que interessava aos objetivos culturais do governo ditatorial. No Museu, deviam ser abrigados objetos ligados aos grandes vultos da História. 
Ao contrário de seu antecessor, que não realizou reformas e adaptações infraestruturais, o general Rocha Almeida propunha a "modernização" do Museu por meio de obras. Afinado pessoal e profissionalmente ${ }^{26} \mathrm{com}$ o programa de prosperidade econômica e planejamento tecnocrático que se impunha com o regime militar, o diretor Rocha Almeida articulou o "milagre econômico" no Museu. As obras de recuperação e restauro podem ser percebidas como resquícios do Compromisso de Brasília ${ }^{27}$, definidor da política de preservação do Estado. Nesse sentido, foi instaurada uma Comissão de Recuperação do Patrimônio Histórico do Estado do Rio Grande do Sul, cujas incumbências eram, entre outras, a reorganização administrativa e a recuperação das instalações do Museu Julio de Castilhos.

Com a visitação suspensa pelas obras, o papel do Museu estava destinado ao de guardião. Na visão daquele gestor e em sua prática profissional, a História só era verdadeiramente genuína a partir dos documentos. Seu maior legado foi desenvolver pesquisas biográficas a respeito da árvore genealógica da família Castilhos e da constituição da edificação-casa que abrigava o Museu. Não houve naquela gestão uma mudança significativa a respeito do pensamento e da prática museológica que o Museu Julio de Castilhos desempenhava. Não se percebe qualificação do espaço ou mudança em relação aos usos da instituição, apenas obras de recuperação e restauro.

No período de 1967 a 1971, no que tange à inclusão de peças no acervo, desenvolveu-se na prática do Museu aquilo que pode ser entendido como "recolhedor passivo" (BITTENCOURT, 2005, p. 156). Não foi encontrada documentação que explique entendimento e preocupação do general Rocha Almeida em constituir uma política de aquisição para o Museu, a não ser a acumulação de 109 peças de representação militar, como indumentárias, bustos, documentos e iconografias de personagens da caserna, como "signos do triunfo". Verificando a análise de Stuart Hall (2011), a construção e a significação das coisas são feitas por representações e classificações, como se pode perceber pelos objetos militares. 
A acumulação das peças militares e sua apresentação nas exposições temporárias do Museu mostram a intenção de sensibilizar a população para a importância da profissão militar, uma vez que o período era propício para tanto. Para Bittencourt (2003, p. 166-167), historicamente as relações do Estado com as populações foram sempre pautadas pela violência, pela qual os objetos bélicos são legitimados como "signos do triunfo". Além do mais, o autor explica a representação preferencial, nos museus históricos, dos vestígios do oficialato, em detrimento dos vestígios dos pracinhas de baixa patente (soldados), ou seja, o discurso hierárquico militar institui a caracterização da expressão do Estado.

Numa iniciativa instigante, e que merece uma avaliação futura mais apurada, transferiu-se a coleção de 625 armamentos, intitulada General Osório, para a guarda do Terceiro Exército. O Museu Julio de Castilhos fora detentor de uma coleção significativa de armamentos, doados por Mario Martinez e tombados pelo Serviço de Patrimônio Histórico e Artístico Nacional (SPHAN) em 1938; o qual incluiu cláusula de extirpar a coleção, caso houvesse, ao longo do tempo, negligência da instituição para com os bens. A coleção de armamentos e munições recebeu baixa do acervo do Museu e foi transferida para o Parque Histórico Marechal Manoel Luiz Osório, estabelecimento militar localizado na cidade de Osório, próximo à capital, Porto Alegre. O referido Parque fora criado para honrar o Patrono da Arma da Cavalaria, instituição em que muitos dos generais que atuavam nos âmbitos governamentais da Ditadura civil-militar fizeram sua formação de caserna.

Nesse período, o papel educativo preconizado para os museus esteve enfatizado, não sendo interessante a permanência de armamentos, mesmo históricos, ao alcance da população, no Museu.

Com o falecimento precoce e inesperado do general e diretor Antônio Rocha Almeida, o Museu Julio de Castilhos passou a ser dirigido por gestores interinos, isto é, funcionários não nomeados oficialmente para o cargo, mas que respondiam pela direção do órgão. Durante um intervalo de três anos, Ivone Martini (1971-1973) e Moacyr Domingues (1973) conduziram a instituição Museu Julio de Castilhos. A primeira preocupou-se com a concretização dos projetos de qualificação e reformulação estrutural, conceitual e administrativo do Museu, iniciados na gestão 
anterior. O segundo diretor, Moacyr Domingues, conseguiu reabrir a instituição; o que não impingiu outro paradigma museológico, já em discussão pelo movimento da Nova Museologia (inspiradora para os profissionais da museologia nacional e internacional). Por serem interinos, considerados ilegítimos perante o campo patrimonial, político e cultural que cercava o Museu Julio de Castilhos, não arranjaram novas proposições. A formação do profissional de museus no Brasil deve-se ao Museu Histórico Nacional, que norteou a organização funcional e conceitual das instituições congêneres. O Museu Julio de Castilhos, por meio dos diretores aqui explicados, reproduziu os padrões do MHN.

O último dos diretores avaliados por esta pesquisa foi Joaquim Carlos de Moraes, atuante no Museu Julio de Castilhos durante os anos de 1974 e 1980. Os pilares de sua administração estiveram ajustados pela comunicação. Cabe explicar que a comunicação desenvolvida no Museu, pelo trabalho orientado por Joaquim Carlos de Moraes, não seguiu uma linha de informação, mas de massificação cultural. Os acervos não eram mais objetos destinados às grandes narrativas, mas patrimônios disponíveis ao consumo das "massas". Os objetos enquanto construções históricoculturais foram qualificados para atendimento das demandas tecnocráticas e modernizadoras de um "país que vai para frente".

A compreensão articulada entre o museu e a escola, bem como o patrimônio constituído pelos museus, servia largamente aos propósitos definidos. Para o diretor Joaquim Moraes, o Museu Júlio de Castilhos era entendido como "Centro Cultural para atividades artísticas e sociais" ${ }^{\prime 2}$. Os centros culturais eram tendência no Brasil desde 1970, além de serem marcados pela característica de construção de cultura num processo de compartilhamento de informações, com música, teatro, exposições $^{29}$. A década de 1970 no Brasil foi marcada por investimentos governamentais significativos na economia, consolidada pelo capital estrangeiro e pela acumulação capitalista, o que configurou a atuação do Estado como indústria cultural.

Joaquim Moraes inventou projetos de exposições temáticas, temporárias e itinerantes que desenvolviam enfoques de homenagem às datas comemorativas do calendário cívico-militar, tais como Dia do Exército, da Marinha, do Índio, 
Independência e República, como exemplifica a imagem digitalizada 2, do recorte do Jornal Diário de Notícias de 26 de agosto de 1974, adiante colocada. Nos jornais da época, é possível encontrar diversas reportagens tratando de solenidades realizadas no Museu por conta da comemoração de determinadas datas ou de homenagens a personalidades consideradas como de grande relevância para a História.

Na concepção apresentada por Marília Cury, exposições são discursos autorizados, produtos finais de uma cadeia operatória iniciada a partir da musealização dos objetos e que se situam numa interface de comunicação entre as instituições museais e os seus públicos. (CURY, 2005). 


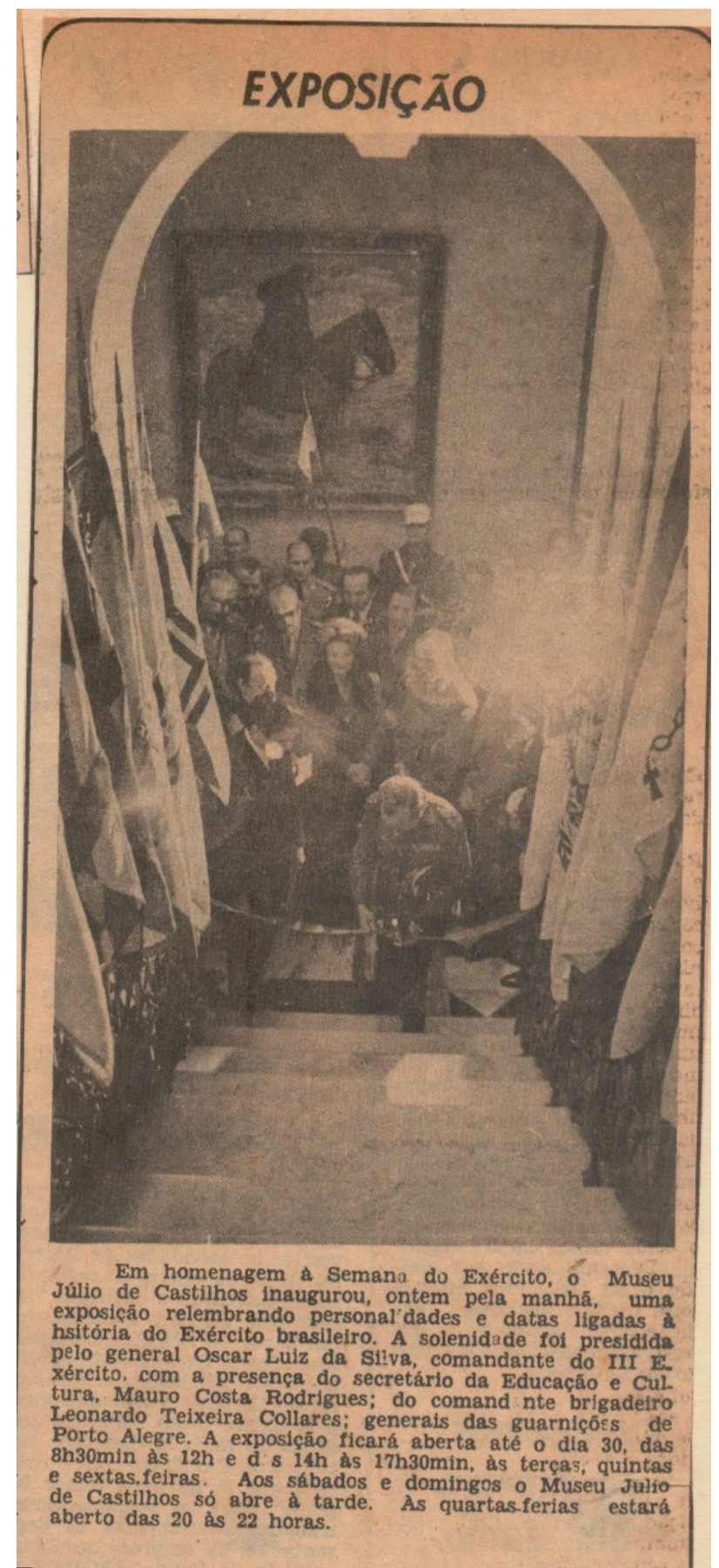

Figura 2 - Cópia digital de recorte de periódico da época (Jornal Diário de Notícias, de 25/8/1974), que noticia que o Museu Julio de Castilhos abre uma exposição comemorativa à Semana do Exército. Fonte: Acervo permanente da pasta de recortes da Biblioteca do Museu Julio de Castilhos, sem número de registro e sem numeração de página.

A verticalidade do processo expositivo e museológico, desenvolvido na gestão de Joaquim Moraes, particulariza um campo de disputas políticas, onde o embate entre lembrança e esquecimento está sempre presente. O que lembrar e o que esquecer, ou a quem interessa manter determinadas lembranças ou conservar na escuridão do 
esquecimento outras tantas, são questões importantes para serem problematizadas, tendo em vista que há sempre um jogo de forças entre memória e poder. Escolher o que lembrar e o que esquecer é, antes de tudo, uma ação política.

Projetos como "Cinema no Museu", "Museu vai à escola", "Museu vai à praia" e "Trem da Cultura" foram experiências desempenhadas por Joaquim Moraes, capazes de mobilizar o encantamento das pessoas, aplicando "intenções governamentais sobre o processo cultural”. (ORTIZ, 1985, p. 90). Uma espécie de "anomalia", termo utilizado por Alves (2009) para descrever os meados dos anos de 1960, nos quais o Brasil vivenciava uma ditadura marcadamente de direita com uma hegemonia cultural caracteristicamente de esquerda.

Há uma tendência, nas estruturas conservadoras, a métodos cada vez mais rígidos de controle social, tais como os incentivos ao setor de comunicação, a censura e o Al-5, que serviram como centralização militar do poder.

Dentre as construções imaginárias do diretor Joaquim Moraes para atender aos propósitos governamentais, a exposição itinerante "Trem da Cultura" merece atenção e destaque. O projeto "Trem da Cultura" consistiu em apresentar uma seleção de acervos do Museu, em vagões pertencentes à antiga Rede Ferroviária Federal S.A. (RFFSA), durante viagens pontuais ao interior do Rio Grande do Sul. A interiorização vinha ao encontro da proposta do Governo do Estado e do Governo Federal, que preconizava a "integração nacional". As mostras do Trem da Cultura constituíram fronteiras de reafirmação e pressão dos agentes culturais e do poder dominante, nos recortes e nas reafirmações das trocas simbólicas. As peças escolhidas para representar o Museu Julio de Castilhos e a "cultura rio-grandense" formavam um gabinete de curiosidades, frente à diversidade de símbolos e referenciais de heróis e mitos da narrativa histórica. Os objetos não estabeleciam relações entre si, não sendo possível articulá-los a partir de um tema ou uma época específica. O mais importante, nas exposições, era exaltar o passado a partir dos objetos que figuravam como provas fiéis de um tempo já vivido.

O projeto formou a imaginação museal em gerações que, possivelmente, tiveram a primeira experiência de contato com bens culturais através de uma de suas três edições, dos anos 1975 a 1977. 
Para o Brasil, que almejava o grau de modernização alcançado por algumas nações, era necessário que houvesse um entendimento de que todos os cidadãos eram importantes para o desenvolvimento do país. Num período em que o anseio pelo progresso definia todo o direcionamento da política do Estado, o museu surge como o lugar ideal para a conscientização da sociedade quanto à importância de colaborar para o engrandecimento do país. Os museus assumiram o papel de instruir e educar a população, sendo utilizados como instrumentos de construção e afirmação dessa memória nacional, que se constituía através das diretrizes do Estado.
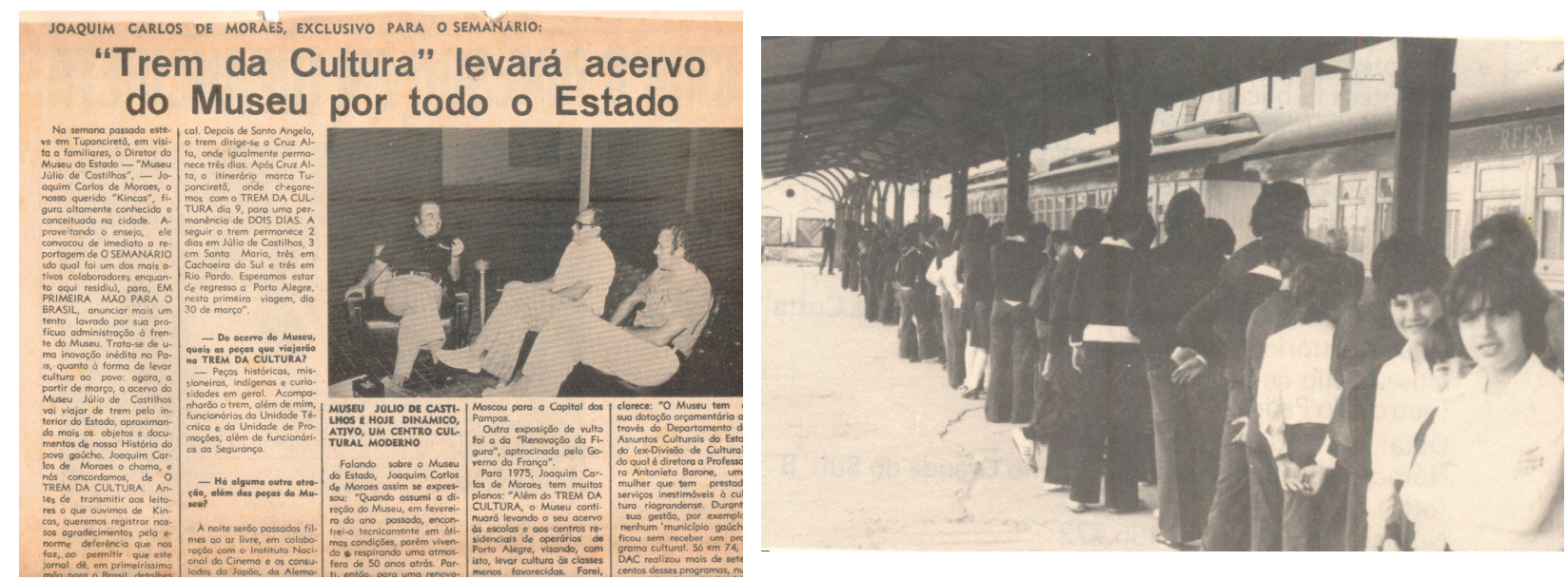

Figuras 3 e 4 - Cópias digitalizadas de fotografias do Projeto Trem da Cultura, respectivamente, edição 1976 e edição 1977. Fonte: Acervo permanente da coleção iconográfica do Museu Julio de Castilhos, sem número de registro ou autoria.

O Museu Julio de Castilhos tornar-se-ia, portanto, o lugar ideal para a apresentação do passado virtuoso a ser venerado. A instituição era vista como meio de fortalecer o vínculo identitário das pessoas com as suas raízes históricas, despertando todos para a importância de se conhecer os assuntos e "personalidades" e para a celebração das glórias de outrora. Era vista também como lugar de construção de memórias, transformado num templo para celebrar os feitos gloriosos de nossos heróis nacionais; os quais, por isso, deveriam tornar-se conhecidos pela população como sujeitos dignos de respeito e veneração.

No entanto, mesmo a aproximação ao exigido pelas demandas do fomentador do Museu, o Governo, não garantiu recursos para o atendimento das necessidades da instituição. 


\section{Considerações finais}

Este artigo abordou diversas situações ocorridas no Museu Julio de Castilhos, durante os anos de 1960 a 1980. Tomar o museu como objeto de investigação histórica é refletir sobre as várias transformações pelas quais passou a instituição ao longo do tempo. É entender seu caráter social e vê-lo como um lugar para se compreender a sociedade e a forma pela qual ela se faz representar.

Pela análise das administrações de Derly Chaves, Antônio Rocha Almeida, Ivone Martini, Moacyr Domingues e Joaquim Carlos de Moraes é possível perceber a dialética entre o museu-templo e o museu-fórum ${ }^{30}$.

No balanço das gestões, contrastes como o Museu ter sido fechado no período de 1967 a 1971, na administração do general Antônio Rocha Almeida, e a utilização excessiva do acervo, entre 1974 e 1980, na gestão de Joaquim Moraes, chamam a atenção para a questão de como o social pouco intervém na elaboração de políticas museológicas e culturais. Por outro lado, na problematização das identidades locais e nacionais, o Museu Julio de Castilhos foi considerado como referência obrigatória para a manutenção da concepção política vigente, como espaço de continuidade do discurso centrado no poder.

A tônica dos quatro momentos - de 1960 a 1967; de 1967 a 1971; de 1971 a 1973 e de 1974 a 1980 - está no contexto histórico, período notadamente marcado por transformações culturais, artísticas, intelectuais, comportamentais, políticas e econômicas. A instituição Museu Julio de Castilhos vivencia esses diferentes momentos de forma paradoxal; afinal museus são sujeitos históricos e, como tais, estão subordinados à história, pois trabalham sob o mesmo registro epistemológico do pensamento ocidental, atravessando dilatações e redefinições, na mesma dinâmica que a sociedade.

A exterioridade social, o panorama social, cultural, político e econômico dos anos de 1960 a 1980, em sua efervescência, influenciaram o processo museológico do Museu Julio de Castilhos. Nessa época, o Museu recebeu reforços de fôlego para atender, inclusive, às diretrizes patrimoniais. Nos anos de 1975 e 1976, em Salvador e Brasília, foram desenvolvidos documentos que compromissavam governos 
estaduais em proteger o patrimônio, com vistas à construção de uma memória única, homogênea, da "Nação como realidade nacional". (SANTOS, 2008, p. 80).

Como museu de história, a instituição Museu Julio de Castilhos demonstra os discursos hierárquicos, autoritários e de uniformização, os quais são constantemente vinculados entre si. O Museu foi transformado em um programa cultural, em que figuram presenças e ausências definidas nas pressões dos seus agentes. Ele não produziu conhecimentos, mas ressignificações idealizadas, de uma sociedade que precisa se conhecer.

Enquanto espaço de representação cultural, o Museu Julio de Castilhos, como ferramenta, cumpriu seu papel de aproximação e afinidade com o Estado, junto à sociedade, vivendo suas leis e regras, de representação política. Interagindo com a sociedade, a instituição Museu Julio de Castilhos foi adaptada à complexidade de sua época. E essa foi a história a que me propus pesquisar e contar.

\section{Notas}

(1) O campo a que me refiro é constituído pelos agentes do Estado (nacional e regional), pelos cinco diretores que administraram o Museu no período em questão, por seus funcionários, por indivíduos e grupos interessados no preservacionismo e, ainda, pela imprensa local.

(2) Somente durante o período de 1960 a 1980, estiveram consultando o Museu Julio de Castilhos para orientação museológica, por meio de correspondências oficiais, as seguintes instituições: CTG Rincão da Saudade de Uruguaiana (1963), Prefeitura Municipal de Caxias do Sul (1964), Prefeitura Municipal de São Borja (1969), Reitoria da Universidade do Rio Grande do Sul (1971), Museu de Carazinho (1972), Prefeitura Municipal de Vacaria (1975), Museu Visconde de São Leopoldo (1975), Prefeitura Municipal de Rio Grande (1979), entre outros.

(3) Alguns autores debruçaram-se sobre o tema. A dissertação de Letícia Nedel (1999), "Paisagens da província: o regionalismo sul-rio-grandense e o Museu Julio de Castilhos nos anos cinquenta" é a referência mais rica em dados e fontes relacionados ao tema. Outros estudos trataram direta ou indiretamente a respeito da história institucional: o artigo de Peretti e Giovanaz (2003), "O museu como lócus de produção da história nacional e regional: o caso do Museu Julio de Castilhos"; Thaís Fraga (2004), com a dissertação "Os subterrâneos emergem: a institucionalização da cultura e a temporada de museus do Rio Grande do Sul”; Marcia Bertotto (2007), com a dissertação "Análise das políticas públicas para museus no Rio Grande do Sul: um estudo da eficácia no desenvolvimento das instituições museológicas"; o artigo de Heloisa Capovilla (2005), "Museu Julio de Castilhos: trajetória histórica e perfil parcial do acervo"; e o artigo de Zita Possamai (2010): "Lição de 'coisas' 
no Museu; o método intuitivo e o Museu do Estado do Rio Grande do Sul, Brasil, nas primeiras décadas do século XX".

(4) Pode-se citar FRAGA (2004), CAPOVILLA (2005), ZAMIN (2006), BERTOTTO (2007), SPINELLI (2008), POSSAMAI (2010) e SILVA (2011).

(5) Os documentos utilizados foram correspondências expedidas e recebidas, relatórios, atas, boletins e registros guardados nos arquivos permanentes do Museu Julio de Castilhos. Também foram examinados recortes de periódicos de publicação diária local, no período compreendido entre 1960 e 1980, como os jornais Correio do Povo, Folha da Tarde, Diário de Notícias, Folha da Manhã e Zero Hora.

(6) O Decreto de Criação do Museu (de n. 589, de 30 de janeiro de 1903, página 1) define os objetivos do Museu do Estado: "Reunir e classificar os produtos do Rio Grande do Sul e todos os elementos que possam ser úteis ao estudo antropológico de seus primitivos habitantes; colecionar artefatos indígenas e que tenham qualquer valor etnológico e bem assim, os produtos de ciência, indústria, artes modernas e documentos históricos de qualquer gênero[...]".

(7) Julio Prates de Castilhos foi líder político de atuação nacional, que no Rio Grande do Sul fundou o Partido Republicano Rio-Grandense e o jornal A Federação, de caráter governista. Para Silva (2011), Julio de Castilhos impingiu a seu governo uma feição modernizadora e autoritária, conforme os preceitos positivistas. Morreu prematuramente de câncer na traqueia, causando forte comoção social. "A evocação da sua memória teve a intenção de consagrá-lo como o grande líder político republicano rio-grandense, afirmando o castilhismo como projeto político vencedor e modelo a ser seguido." (SILVA, 2011, p. 11).

(8) Nos documentos analisados durante a pesquisa, tais como certificados e os discursos de posse e despedida dos diretores Derly Chaves (1960-1967) e Antônio Rocha Almeida (1967-1971), o Instituto Histórico e Geográfico do RIO Grande do Sul foi citado como "parceiro" do Museu Julio de Castilhos, sendo o General Rocha Almeida membro do IHGRGS.

(9) O período coincide com a criação da Associação Nacional dos Professores Universitários de História, ANPUH, institucionalização do campo de conhecimento disciplinar da história que ensejava a delimitação de um espaço profissional para a tarefa de escrevê-la. Alguns dos membros do IHGRGS, como o próprio ex-diretor do Museu Julio de Castilhos, Dante de Laytano, figuram como professores universitários dos cursos de História nas Universidades de Porto Alegre.

(10) Para BACKUP (2005), o então diretor do Museu Julio de Castilhos, Dante de Laytano, historiador, incentivador dos estudos regionalistas, vinculado ao IHGRGS, foi o responsável por alavancar a transformação da instituição para operar, exclusivamente, com a tipologia histórica, priorizando o folclore e o estudo das tradições.

(11) Nos documentos recebidos há indicação de pedidos e negativas de transferências de posse, entre os diretores do MJC e do MARGS, a respeito das estatuárias missioneiras (o Santo Antônio Xavier figura como imagem de capa do catálogo anual do MARGS) e obras em óleo sobre tela, mostrando uma discussão a cerca da tipologia das peças. 
(12) A expressão foi utilizada por Waldissa Rússio, que compreendeu o fato museal como o processo de comunicação e apreensão da ideia proposta (conhecimento) por meio da exposição do objeto (coleção), em um cenário (museus). Ver: Maria Bruno, em Waldissa Rússio Camargo Guarnieri. Textos e contextos de uma trajetória profissional. São Paulo: Pinacoteca do Estado de São Paulo, Secretaria da Cultura. Comitê Brasileiro do Conselho Internacional de Museus, 2010. 312 p.

(13) Esses personagens eram considerados os intelectuais ligados à base identitária e às academias históricas do Rio Grande do Sul. Ver a dissertação de Letícia Nedel: Paisagens da província: o regionalismo sul-riograndense e o Museu Julio de Castilhos nos anos 1950. Dissertação do Mestrado em História do Instituto de Filosofia e Ciências Humanas da Universidade Federal do Rio de Janeiro, 1999.

(14) A alteração da missão do Museu Julio de Castilhos não foi realizada em seu Regimento Interno, firmado em 1943 e ainda vigente. Fonte: Arquivo permanente do Museu Julio de Castilhos, capítulo primeiro do Regimento.

(15) A designação cultura material foi embasada no que refere MENESES (1998) como os objetos, peças e artefatos de produção humana que representam uma sociedade. Ver: Ulpiano Bezerra Meneses,. Memória e cultura material: documentos pessoais no espaço público. Revista Estudos Históricos, Rio de Janeiro, Fundação Getúlio Vargas, vol. 11, n. 2, 1998.

(16) A Revolução Farroupilha foi um episódio entre o Rio Grande do Sul e o poder central imperial ocorrido entre 1835-1845, que serviu como fato fundador da construção histórica da sociedade rio-grandense, acionada a partir das décadas de 1930-1950 como reação imediata às crises culturais, econômicas e de identidade do Estado. Uma visão romântica de buscar no passado o entendimento do presente.

(17) O acervo do Museu Julio de Castilhos foi tombado pelo Instituto de Patrimônio Histórico e Artístico Nacional em 1937, no Livro Tombo das Belas Artes. Não estão especificados individualmente os acervos tombados. Na forma como são considerados pelo IPHAN todos os acervos foram incorporados, ficando o Museu Julio com uma "coleção aberta", em constante aquisição.

(18) Desde o século XIX, os museus de história foram considerados depositários de objetos ecléticos, locais em que o passado era celebrado a partir da narrativa de vida de personagens e fatos historicamente construídos e estabelecidos como verdadeiros. Seus objetos musealizados eram consagrados pela testemunhalidade, autenticidade e preciosidade. Atualmente, segundo Meneses, convém conceber um museu de história, "não como a instituição voltada para os objetos históricos, mas para os problemas históricos".

(19) Na prática museológica, as incorporações de coleções e peças são denominadas de aquisições; as quais podem ser realizadas por meio de compra, doação, permuta, empréstimo, legado ou coleta. As aquisições no Museu Julio de Castilhos dão-se por meio de doações de particulares ou por transferência das instituições vinculadas ao poder público estadual ou federal. No período entre 1960 e 1980, foram realizadas 1.646 aquisições, sendo as mais recorrentes: armas, documentos, iconografias, indumentárias, moedas, livros e objetos de uso pessoal, formando um total de 24 coleções. Atualmente, o Museu possui 29 coleções e 11.904 objetos. 
(20) A incorporação de uma lambreta como acervo do Museu Julio de Castilhos na coleção de viaturas, deve-se à amizade entre o diretor Joaquim Moraes e o doador José Ferreira da Silva que rodou com o veículo por alguns países, conforme relata a ficha de entrada, documentação museológica do acervo.

(21) A musealização de objetos, na acepção de BRUNO (1996, p. 56), "é o processo constituído por um conjunto de fatores e diversos procedimentos que possibilitam que parcelas do patrimônio cultural se transformem em herança, na medida em que é alvo de preservação e comunicação".

(22) Discurso de posse do diretor Derly Chaves, documento do arquivo permanente do Museu Júlio de Castilhos.

(23) Op. Cit. p. 19.

(24) A informação é dada pela Chefe do Setor Técnico e Departamento Histórico do Museu, Maria José Lopes Daudt, em seu relatório anual (17set. 1964).

(25) Conforme o roteiro e guia de visitação do Museu Julio de Castilhos (1978), as salas eram assim constituídas: Sala Colônia, Sala Império, Sala República, Sala Porto Alegre Sala Julio de Castilhos, Sala Missões, Salas Indígenas (três), Sala Gaúcha e Sala Brigada Militar.

(26) Lembrando que Antônio Rocha Almeida constituiu sua carreira profissional nas fileiras do Exército, chegando ao posto de General de Brigada, recebedor de diversas condecorações da Ordem Militar. Esteve ligado a diferentes instituições, como a Academia Rio-Grandense de Letras, Gabinete Português de Leitura, Instituto Histórico e Geográfico do Rio Grande do Sul, Instituto de Geografia e História Militar do Brasil e Instituto Genealógico do Rio do Sul. Além disso, era jornalista profissional, registrado no Ministério do Trabalho. Essas experiências pessoais impunham-se como marcas nas atividades museológicas.

(27) Reunião de autoridades em Brasília, em 1970, que delegou aos Estados e Municípios a competência e o comprometimento com a preservação e a proteção do patrimônio nacional. Ver: Cartas Patrimoniais, IPHAN, 2004 , p. 137.

(28) Referenciado no Boletim do Museu Julio de Castilhos, n. 1, de março a setembro de 1974, página 1. Arquivo permanente da instituição.

(29) Ver: Lígia Dabul, Museu de grandes novidades: centros culturais e seu público. Horizontes Antropológicos, Porto Alegre, vol. 14, n.29. jan./jun. 2008. Disponível em: <http://www.scielo.br/scielo. phpp? script=SCl_arttext\&pid=5 0104-71832008000100011>.

(30) Referência ao texto de Ulpiano Bezerra de Menezes: Do teatro da memória ao laboratório da história: a exposição museológica e o conhecimento histórico. Museu Paulista: história e cultura material. Anais. Vol. 2. jan./dez., 1992. São Paulo: Editora da USP, 1994. 


\section{Referências bibliográficas}

ABREU, Regina. A fabricação do imortal: memória, história e estratégias de consagração no Brasil. Rio de Janeiro: Lapa/Rocco, 1996.

ALVES, Clarissa S. A ditadura civil-militar no Brasil e as políticas educacionais. Monografia (Curso de História), Instituto de Filosofia e Ciências Humanas, Universidade Federal do Rio Grande do Sul/UFGRS, Porto Alegre, 2009.

BACKUP, Jorge. 50 anos da Fundação Zoobotânica do Rio Grande do Sul. Porto Alegre: Câmera Rio-Grandense do Livro, 2005.

BANN, Stephen. As invenções da história: ensaios sobre a representação do passado. São Paulo: Unesp, 1994.

BERTOTTO, Márcia. Museologia no século XXI: o desafio das políticas públicas. In: PEIXOTO, Leo (Org.). Sociedade, conhecimento e interdisciplinaridade: abordagens contemporâneas. Passo Fundo: Editora Universidade de Passo Fundo. 2007, p. 128-168.

BITTENCOURT, José Neves. Sobre uma política de aquisição para o futuro. Cadernos Museológicos $n$, 3, Secretaria da Cultura - IBPC, p. 29-37, out. 1990.

Cada coisa em seu lugar: ensaio de interpretação do discurso de um museu de história. Museu Paulista. Anais do Museu Paulista. vols. 8/9, 2000/2001.

Uma experiência em processo. In: TOSTES, Vera (org.). História representada: o dilema dos museus. Rio de Janeiro, Livro do Seminário internacional. Rio de Janeiro: MHN, MinC/ IPHAN, 2003.

O patrimônio como categoria de pensamento. In CHAGAS, Mario; ABREU, Regina (Org.). Memória e patrimônio: ensaios contemporâneos. Rio de Janeiro: DP\&A Editora, 2003.

Receita para refeição cotidiana dos museus. In: Revista do IPHAN, Rio de Janeiro, n. 31, p. 148-163, Rio de Janeiro: MinC/IPHAN, 2005. Rio de Janeiro: MinC/IPHAN, 2005.

A pesquisa como cultura institucional: objetos, política de aquisição e identidades nos museus brasileiros. In: GRANATO, Marcos; SANTOS, Claudia Penha. Museus instituições de pesquisa. Rio de Janeiro: MAST, 2005. p. 37-50.

BOURDIEU, Pierre. O poder simbólico. Rio de Janeiro: Difel, 1996.

O amor pela arte: os museus de arte e seu público. São Paulo: Edusp, 2003.

BOURKE, Peter. Testemunha ocular: história e imagem. Bauru, São Paulo: Edusp, 2004.

BRASIL. Ministério da Cultura. IPHAN/ DEMU. Relatório de gestão da Política Nacional de Museus 2003-2004. Brasília, 2005. 
Política Nacional de Museus: relatório de gestão 2003-2006. Brasília: MinC/IPHAN/DEMU, 2006.

BRUNO: Cristina. Museologia e comunicação. Cadernos de sociomuseologia. Lisboa: Centros de Estudos de Sociomuseologia, Universidade Lusófona de Humanidades e Tecnologia, 1996. vol. 9.

Waldissa Rússio Camargo Guarnieri, textos e contextos de uma trajetória profissional. São Paulo: Pinacoteca do Estado de São Paulo: Secretaria da Cultura, Comitê Brasileiro do Conselho Internacional de Museus, 2010.

CANCLINI, Nestor Garcia. Culturas híbridas: estratégias para entrar e sair da modernidade. São Paulo: Edusp, 1998.

. O patrimônio cultural e a construção imaginária do nacional. Revista do IPHAN, n. 23, Rio de Janeiro, 1994.

CAPOVILLA, Eloisa H. L. Ramos. Museu Julio de Castilhos: trajetória histórica e parcial de um acervo. In: AXT, Gunter (Org.). Julio de Castilhos e o paradoxo republicano. Porto Alegre: Nova Prova, 2005. p. 265-279.

CHAGAS, Mario de Souza. Museália. Rio de Janeiro: JC Editora, 1996.

Memória e poder: dois movimentos. Dissertação de mestrado em Museologia. Universidade Lusófona de Humanidades, Lisboa, 2000.

A imaginação museal: museu, memória e poder em Gustavo Barroso, Gilberto Freyre e Darcy Ribeiro. Rio de Janeiro: MinC/IBRAM, 2009.

CHARTIER, Roger. A história cultural: entre práticas e representações. Tradução Maria Manuela Galhardo. Rio de Janeiro: Bertrand Brasil, 1990.

O mundo como representação. Estudos Avançados, São Paulo. Vol. 11. n. 5, p. 173-191, 1991.

CHOAY, Françoise. A alegoria do patrimônio. São Paulo: Estação Liberdade/Unesp, 2001.

COELHO, Teixeira. Dicionário crítico de política cultural: cultura e imaginário. São Paulo: lluminuras, Fapesp, 1997.

CURY, Marília Xavier. Exposição: concepção, montagem e avaliação. São Paulo: Annablume, 2005.

DABUL, Lígia. Museu de grandes novidades: centros culturais e seu público. Horizontes Antropológicos, vol. 14, n. 29. Porto Alegre, jan./jun. 2008. Disponível em: <http:// www.scielo.br/scielo.php?script=50104718320080001000011>. Acesso em: 24 set. 2011.

FELIX, Loiva. A fabricação do carisma: a construção mítico-heroica na memória republicana gaúcha. In: FELIX, Loiva; ELMIR, Claudio (Org.). Mitos e heróis: construção de imaginários. Porto Alegre: Editora Universidade/UFRGS, 1998. 
FRAGA, Thais. Os subterrâneos emergem à institucionalização da cultura e à temporada dos museus No Rio Grande do Sul (1987-1991). Dissertação de mestrado em História pelo Instituto de Filosofia e Ciências Humanas, Universidade Federal do Rio Grande do Sul: Porto Alegre, 2004.

FOUCAULT, Michel. Microfísica do poder. Rio de Janeiro: Ed. Graal, 1995. A ordem do discurso. São Paulo: Edições Loyola, 1996.

GASPARI, Elio. A ditadura escancarada. São Paulo: Companhia das Letras, 2002.

GIRAUDY, Daniele. O museu e a vida. Rio de Janeiro: Fundação Nacional Pró-memória; Porto Alegre: Instituto Estadual do Livro, RS; Belo Horizonte: UFMG, 1990.

GONÇALVES, José Reginaldo Santos. Ressonância, materialidade e subjetividade: as culturas como patrimônios. Horizontes Antropológicos, Porto Alegre, ano 11, n. 23, p. 15-356, jan./jun. 2005. p. 15-36.

A retórica da perda: os discursos do patrimônio cultural no Brasil. Rio de Janeiro: Editora UFRJ/Min C/IPHAN, 1996.

O templo e o fórum: reflexões sobre museus, antropologia e cultura. In: A invenção do patrimônio: continuidade e ruptura na constituição de uma política oficial de preservação no Brasil. Rio de Janeiro: MinC, IPHAN, 1995.

O patrimônio como categoria de pensamento. In: ABREU, Regina; CHAGAS, Mario (Orgs.). Memória e patrimônio: ensaios contemporâneos. Rio de Janeiro: DP\&A Editora, 2003.

GRILL, Rosalind. Análise do discurso. In: Pesquisa qualitativa com textos, imagens e sons: um manual prático. 3. ed. Petrópolis (RJ): Vozes, 2002.

HALL, Stuart. A identidade cultural na pós-modernidade. 11. ed. Rio de Janeiro: DP\&A, 2011.

HOBSBAWM, Eric. J. Nações e nacionalismo desde 1780: programa, mito e realidade. Rio de Janeiro: Paz e Terra, 1990

HUNT, Lynn (Org). A nova história cultural. São Paulo: Martins Fontes, 1992.

HUYSSEN, Andreas. Escapando da amnésia: o museu como cultura de massa. Revista do Patrimônio Histórico e Artístico Nacional, n. 23, p. 35-37, 1994.

MENESES, Ulpiano Bezerra. História cativa da memória? Para um mapeamento da memória no campo das ciências sociais. Revista do Instituto de Estudos Brasileiros, n. 34, p. 9-24, 1992.

Para que serve um museu histórico? In: Como explorar um museu histórico? São Paulo: Editor Museu Paulista da USP, 1992. 
Do teatro da memória ao laboratório de história: a exposição museológica e o conhecimento histórico. Museu Paulista: história e cultura material. Anais do Museu Paulista. 2, jan./dez., 194, São Paulo: Edusp, 1994.

Memória e cultura material: documentos pessoais no espaço público. Revista Estudos Históricos, Rio de Janeiro, Fundação Getúlio Vargas, vol. 11, n. 2, 1998.

LE GOFF, Jacques. História e memória. Tradução de Bernardo Leitão. $5^{\circ}$ Ed. Campinas: Editora da UNICAMP. 2003.

NEDEL, Letícia Borges. Paisagens da província: o regionalismo sul-rio-grandense e o Museu Julio de Castilhos nos anos 1950. Dissertação de mestrado em História pelo Instituto Filosofia e Ciências Humanas, Universidade Federal do Rio de Janeiro, Rio de Janeiro, 1999.

Breviário de um museu mutante. Horizontes Antropológicos, Porto Alegre, ano 11, n 23, p. 15-36, jan./jun., 2005. p.15-36.

NORA, Pierre. Entre história e memória: a problemática dos lugares. São Paulo: Unicamp, 1993. Projeto História.

ORTIZ, Renato. Cultura brasileira e identidade nacional. São Paulo: Brasiliense, 1985.

A moderna tradição brasileira. São Paulo: Brasiliense, 1988.

PESAVENTO, Sandra J. Em busca de outra história: imaginando o imaginário. Revista Brasileira de História, São Paulo, vol. 15, n. 29, p. 9-27, 1995.

História cultural: experiências de pesquisa. Porto Alegre: Ed. Universidade, 2003.

História e História Cultural. São Paulo: Autêntica, 2008.

A invenção da sociedade gaúcha. Ensaios F. E. E. Porto Alegre, 2009.

PERETTI, Luis Armando; GIOVANAZ, Marlise. Museu como lócus de produção regional: o caso do Museu Julio de Castilhos. Revista de Iniciação Científica da ULBRA, Canoas, vol. 1, n. 2, p. 159-168, 2003. Canoas: Ed. Ulbra. 2003.

PERICHI, Ciro. O que é museografia? In: ARNAUT, Jurema; ALMEIDA, Cícero. (Org.) Museografia: a linguagem dos museus a serviço da sociedade e de seu patrimônio cultural. Rio de Janeiro: IPHAN, 1997.

POMIAM, Kryzstof. “Coleção”. Enciclopedia Einaudi. Lisboa: Imprensa Nacional/Casa da Moeda, 1984, vol.1. Memória e História.

POSSAMAI, Zita Rosane. Nos bastidores do museu: patrimônio e passado da cidade de Porto Alegre. Porto Alegre: EST Edições, 2001. 
Lições das coisas no museu: o método intuitivo e o Museu do Estado do Rio Grande do Sul, Brasil, nas primeiras décadas do século XX. In: VIII Congresso Luso-Brasileiro de História da Educação, 2010, São Luís. VIII Congresso Luso-Brasileiro de História da Educação - Infância, juventude e relações de gênero na História da Educação. São Luís: UFMA, 2010.

POULOT, Dominique. Uma história do patrimônio no Ocidente: séculos XVIII-XXI. São Paulo: Estação Liberdade, 2009.

RAMOS, Francisco Regis Lopes. A danação do objeto: o museu no ensino da história. Chapecó: Argos Editora Universitária, 2004.

Reflexões sobre exposições em museus de História. In: JULIÃO, Letícia (Org.). Cadernos de Diretrizes Museológicas 2. Belo Horizonte: Secretaria da Cultura de Minas Gerais Superintendência de Museus, 2008.

Em nome do objeto: museus; história e sociedade de consumo. In: MILDER, Saul; OLIVEIRA, Joseane (Org.). Patrimônio cultural: experiências plurais. Santa Maria: Pallotti, 2008. p. 35-78.

SANTOS, Maria Célia Teixeira Moura. Repensando a ação cultural e educativa dos museus. 2. ed. Salvador: Centro Editorial e Didático da UFBA, 1993.

O papel dos museus na construção de uma identidade nacional. Anais do Museu Histórico Nacional. Vol. 28. Rio de Janeiro: Museu Histórico Nacional, 1996.

Encontros museológicos: reflexões sobre a museologia, a educação e o museu. Rio de Janeiro: Minc/IPHAN/DEMU, 2008. Coleção Museu Memória e Cidadania.

SANTOS, Myriam Sepúlveda. A escrita do passado nos museus históricos. Rio de Janeiro: Garamound, MINC, IPHAN, DEMU, 2006.

SCHWARCZ, Lilia K. Moritz. A era dos museus de etnografia no Brasil: o Museu Paulista, o Museu Nacional e o Museu Paraense em finais do século XIX. In: FIGUEIREDO, Betânia, VIDAL, Diana. Museus: dos gabinetes de curiosidades ao museu moderno. Belo Horizonte: Argumentum, 2005.

SILVA, Ana Celina F. O Museu e a consagração da memória de Julio de Castilhos. Monografia (Curso de Museologia), Faculdade de Biblioteconomia e Comunicação, Universidade Federal do Rio Grande do Sul/UFRGS, Porto Alegre, 2011.

SOUZA, Daniel M. Museus históricos e sociedade do espetáculo: separação e exclusão através da exposição museológica. Monografia (Escola de Museologia), Centro de Ciências Humanas, Universidade Federal do Rio de Janeiro/UNIRIO, Rio de Janeiro, 2004.

SPINELLI, Teniza. Política museológica: subsídios para uma história da museologia no Rio Grande do Sul. Porto Alegre, 1990. [Mimeografado]. 
Esculturas missioneiras em museus do Rio Grande do Sul. Porto Alegre: ALF, 2008.

SUANO, Marlene. O que é museu? São Paulo: Brasiliense, 1986.

TEIXEIRA, Francisco. História do Brasil contemporâneo. São Paulo: Editora Ática, 1993.

TIMOTHY, Ambroise; CRISPIN, Paine. Política de aquisição. Museum Basic. London: Routledge/lcom, 1993.

ZAMIN, Frinéia. Patrimônio cultural no Rio Grande do Sul: atribuição de valores a uma memória coletiva. Dissertação de mestrado em História pela Universidade Federal do Rio Grande do Sul/UFRGS, Porto Alegre, 2006.

\section{Créditos}

"Andréa Reis da Silveira é historiadora, especialista em museologia e patrimônio cultural, Mestre em Patrimônio Cultural pela Universidade Federal de Santa Maria e graduanda do curso de Museologia da Universidade Federal do Rio Grande do Sul. Foi coordenadora técnica do Museu Júlio de Castilhos entre os anos de 2007 a 2010. A pesquisa de que trata o presente artigo é fruto da dissertação de mestrado do Programa de Pósgraduação Profissionalizante em Patrimônio Cultural da Universidade Federal de Santa Maria, defendida em dezembro de 2011 e intitulada: O Museu Júlio de Castilhos no período 1960-1980: acervos, discursos, representações e práticas através de uma exposição museológica, com orientação da Professora Dra. Maria Medianeira Padoin. Contatos com a autora podem ser feitos através do endereço eletrônico: andrears@terra.com.br. 